Folia Cardiologica 2017 tom 12 , nr 3, strony 306-316 DOI: 10.5603/FC.2017.0060 Copyright @ 2017 Via Medica ISSN 2353-7752

\title{
Leczenie ostrej niewydolności serca
}

\author{
Treatment of acute heart failure
}

\author{
Anna Praska-Ogińska, Janusz Bednarski
}

Oddział Kardiologiczny Specjalistycznego Szpitala Zachodniego im. św. Jana Pawła II w Grodzisku Mazowieckim

\section{Streszczenie}

Ostra niewydolność serca (AHF) stanowi poważny problem socjoekonomiczny współczesnego świata. Niewydolność serca (HF) występuje u około $10 \mathrm{mln}$ osób w Europie i u około 800 tys. w Polsce. W opiece nad chorym wysiłki lekarzy zmierzają jednocześnie do zmniejszenia objawów związanych z HF, odpowiedniego leczenia chorób prowadzących do jej rozwoju oraz do obniżenia ryzyka śmiertelności i rehospitalizacji. Artykuł ten stanowi podsumowanie aktualnej wiedzy na temat leczenia AHF opartej na wytycznych Europejskiego Towarzystwa Kardiologicznego z 2016 roku oraz trwających wieloośrodkowych badaniach klinicznych.

Słowa kluczowe: ostra niewydolność serca, diuretyki, leki inotropowe, ularytyd, serelaksyna

Folia Cardiologica 2017; 12, 3: 306-316

\section{Wstęp}

Ostra niewydolność serca (AHF, acute heart failure) definiowana jest jako nagłe bądź gwałtowne pojawienie się lub pogorszenie istniejących podmiotowych i przedmiotowych objawów niewydolności serca, wymagających pilnej hospitalizacji [1]. Postrzegana przez niektórych jako objaw bądź skrajna faza chorób układu sercowo-naczyniowego, stanowi bezpośredni stan zagrożenia życia. Starzejące się społeczeństwo, z wydłużającym się średnim wiekiem życia z jednej strony, a z drugiej strony rozwój nowych technik kardiologii interwencyjnej i elektroterapii, stawiają przed współczesną medycyną problem narastającej liczby hospitalizacji z powodu niewydolności serca.

\section{Epidemiologia}

Ocenia się, że w ostatnich dekadach doszło do dwukrotnego zwiększenia liczby chorych z niewydolnością serca (HF, heart failure), a zachorowalność wynosi obecnie 1-2\%, co sprawia, że w Europie choroba ta występuje u około 10 milionów osób i u około 800 tysięcy w Polsce. Częstość występowania HF wzrasta, jak już wspomniano wcześniej, wraz z wydłużaniem się czasu życia w populacji oraz poprawą leczenia innych chorób. Największa zachorowalność dotyczy osób po 70. roku życia, wśród których odsetek chorych na HF przekracza $10 \%$.

Niewydolność serca należy do chorób o bardzo złym rokowaniu, zwłaszcza gdy odpowiednio wcześnie nie zostanie zastosowane optymalne leczenie. W grupie chorych przyjmowanych do szpitala z AHF, czyli najczęściej takich, u których stwierdza się objawy w III lub IV klasie według New York Heart Association (NYHA), śmiertelność roczna wynosi 40-60\%.

Wykazano również 30-procentową częstość rehospitalizacji oraz 10-procentową częstość zgonów w ciągu pierwszych sześciu miesięcy po wypisie. Konieczność stosowania leków inotropowych drastycznie pogarsza rokowanie.

Według danych Instytutu Zarządzania w Ochronie Zdrowia w Polsce HF jest przyczyną około 60 tysięcy zgonów rocznie. Jest więc wyższa niż w przypadku większości chorób nowotworowych. Polska posiada również jeden

Adres do korespondencji: lek. Anna Praska-Ogińska, Oddział Kardiologiczny, Specjalistyczny Szpital Zachodni im. św. Jana Pawła II, Daleka 11, 05-825 Grodzisku Mazowieckim, e-mail: a.praskaoginska@gmail.com 
z najgorszych w Europie wskaźników liczby hospitalizacji z powodu HF w przeliczeniu na 100 tysięcy mieszkańców, co wynika, przede wszystkim z niedostatecznej opieki ambulatoryjnej oraz nieodpowiedniej edukacji pacjentów i ich rodzin.

W 2012 roku hospitalizowano 2,5 razy więcej pacjentów z HF niż z ostrym zespołem wieńcowym, co pochłonęło 94\% wszystkich środków przeznaczonych na diagnostykę i leczenie HF [2]. Na podstawie prowadzonych w wielu krajach rejestrów można przeanalizować charakterystykę kliniczną pacjentów hospitalizowanych z powodu AHF. Z rejestrów, takich jak ADHERE, OPTIMIZE-HF, EHFS II, EFICA, ITALIAN AHF, ESC-HF Pilot Survey wynika, że ostra niewydolność serca dotyczy głównie pacjentów w starszym wieku - średni wiek wynosi 75 lat, a najczęstszą postacią kliniczną AHF jest zdekompensowana przewlekła HF [3-7]. U kobiet częściej niż u mężczyzn występuje nadciśnienie tętnicze, mężczyźni częściej chorują na chorobę wieńcową. Porównując powyższe dane z charakterystyką kliniczną polskich pacjentów, zwraca uwagę młodszy wiek polskich chorych i częstsze występowanie chorób towarzyszących. Eksperci tłumaczą to brakiem wystarczającej profilaktyki prozdrowotnej naszego społeczeństwa.

W nowych wytycznych z 2016 roku, dotyczących ostrej i przewlekłej HF, kładzie się nacisk na konieczność pilnego wdrożenia działań diagnostyczno-terapeutycznych u pacjentów trafiających do szpitala z powodu AHF. Podobnie jak w ostrym zespole wieńcowym obowiązuje zasada „czas to narząd", co oznacza, że przedłużający się pierwszy okres hospitalizacji powoduje niekiedy nieodwracalne zmiany narządowe.

\section{Podział}

W literaturze funkcjonują różne podziały AHF, wśród nich klasyfikacja Forrestera oparta na obserwacji pacjentów z ostrym zespołem wieńcowym, uwzględniająca dwa parametry kliniczne - ocenę perfuzji obwodowej (ciepły v. zimny) oraz obecność zastoju w łożysku płucnym (suchy v. mokry), która znalazła odzwierciedlenie w zalecanym schemacie postępowania z pacjentem z AHF. Przydatną klinicznie, szczególnie pod kątem ordynacji leków, jest klasyfikacja uwzględniająca wartość skurczowego ciśnienia tętniczego. Według niej chorych można przydzielić do jednej z trzech grup - chorzy z AHF z wysokim ciśnieniem tętniczym ponad $140 \mathrm{~mm} \mathrm{Hg}$, chorzy w normotensji 140-90 mm Hg oraz chorzy z niskim ciśnieniem tętniczym poniżej $90 \mathrm{~mm} \mathrm{Hg.}$ Pozostałe klasyfikacje, ze względu na ich mniejszą wartość praktyczną, zostały pominięte w niniejszym opracowaniu.

\section{Patogeneza}

W AHF zostaje zachwiana podstawowa funkcja serca, jaką jest dostarczenie adekwatnej objętości krwi w określonej jednostce czasu do tkanek i narządów, w celu zabezpieczenia ich metabolizmu. Ostrą niewydolność serca charakteryzuje spadek rzutu minutowego, który jest determinowany kurczliwością mięśnia serca, obciążeniem wstępnym i następczym oraz częstością pracy serca. Na skutek spadku rzutu serca organizm uruchamia mechanizmy kompensacyjne - mechanizmy sercowe wpływające na siłę skurczu, częstość pracy serca oraz mechanizmy pozasercowe, do których należą reakcje neurohumoralne (autonomiczny układ nerwowy, układ renina-angiotensyna-aldosteron [RAA], peptydy natriuretyczne) oraz mechanizmy obwodowe - centralizacja krążenia. Mechanizmy kompensacyjne kosztem zabezpieczenia priorytetowych narządów organizmu wpływają często na niedokrwienie narządów o mniejszym znaczeniu strategicznym, takich jak nerki czy wątroba. Potencjalne przyczyny AHF przedstawiono w tabeli $1[1,8]$, natomiast algorytm postępowania wstępnego u takiego pacjenta ukazano na rycinie 1.

\section{Rozpoznanie}

Podstawową rolę w rozpoznaniu AHF pełni badanie podmiotowe, przedmiotowe oraz wyniki badań laboratoryjnych i obrazowych. Za patognomoniczny objaw HF uważa się obecność III tonu serca. Diagnostyka i leczenie (na ogół objawowe) jest prowadzone równolegle. W przypadku zdiagnozowania odwracalnej przyczyny dekompensacji można wdrożyć leczenie przyczynowe (ostry zespół wieńcowy, mechaniczne powikłania zawału, rozwarstwienie aorty, arytmie, ciężkie wady zastawkowe) (tab. 2).

Jednym z elementów diagnostyki AHF jest oznaczanie stężenia peptydów natriuretycznych. Punktem odcięcia do rozpoznania AHF jest wartość 300 pg/ml N-końcowego fragmentu propeptydu natriuretycznego typu B (NT-proBNP, $\mathrm{N}$-terminal B-type natriuretic propeptide), $100 \mathrm{pg} / \mathrm{ml}$ peptydu natriuretyczny typu B (BNP, B-type natriuretic peptide) oraz $120 \mathrm{pmol} / \mathrm{l}$ środkowego fragmentu peptydu natriuretycznego typu A (middle area of the front of atrial natriuretic peptide). Metoda nie jest wolna od ograniczeń - otyłość, szybkie i skuteczne leczenie ostrego epizodu może dawać fałszywie ujemne wyniki. Pozostałe parametry laboratoryjne, oceniane u chorego trafiającego do szpitala, dają możliwość rozpoznania patologii wymagających pilnej korekcji oraz pozwalają oszacować ryzyko zgonu. Do podstawowych oznaczeń należą: morfologia, elektrolity, parametry nerkowe i wątrobowe, gazometria, układ krzepnięcia, hormon tyreotropowy (TSH, thyreotropin-stimulating hormone,) i białko C-reaktywne (CRP, C-reactive protein). Do badań obrazowych należy badanie radiologiczne (RTG) klatki piersiowej i badanie echokardiograficzne. Coraz szersze zastosowanie znajduje ultrasonografia (USG) płuc, w której wykrycie artefaktów, tak zwanych komet, sugeruje obecność zastoju śródmiąższowego. Poza powyższymi badaniami nieodzowne 
Tabela 1. Przyczyny i czynniki ryzyka ostrej niewydolności serca (zmodyfikowano na podstawie $[1,8]$ )

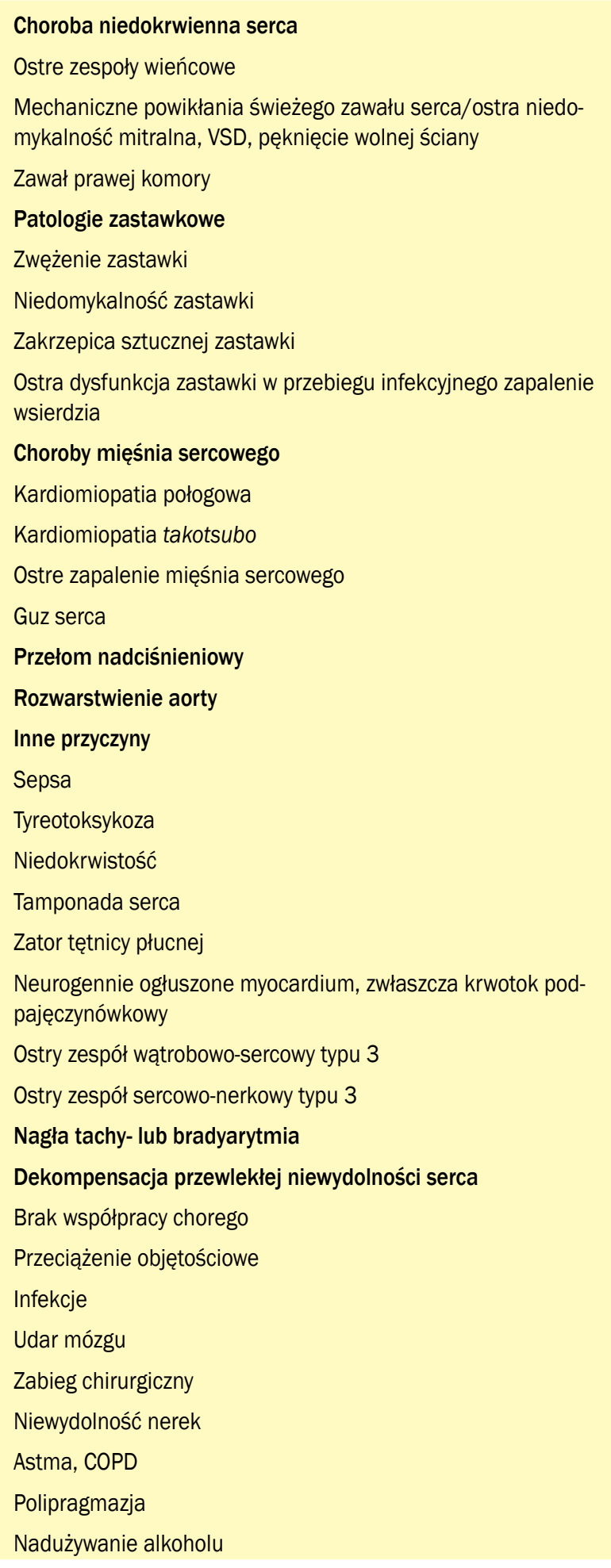

VSD (ventricular septal defect) - ubytek w przegrodzie międzykomorowej; COPD (chronic obstructive pulmonary disease) - przewlekła obturacyjna choroba płuc

u pacjenta z AHF jest wykonanie badania elektrokardiograficznego (EKG). Chorzy z podejrzeniem wodobrzusza mogą wymagać badania USG jamy brzusznej.

\section{Leczenie}

Postępowanie terapeutyczne u chorych z AHF polega głównie na zmniejszeniu zapotrzebowania serca na tlen, poprawie jego kurczliwości, zmniejszeniu obciążenia wstępnego i następczego oraz zapewnieniu prawidłowego przepływu tkankowego. Celem powyższych działań jest zniesienie objawów, ograniczenie uszkodzenia narządów oraz zabezpieczenie chorego przed koniecznością kolejnej hospitalizacji. Podstawowymi lekami są: diuretyki oraz w zależności od wartości ciśnienia tętniczego leki wazodylatacyjne lub aminy katecholowe.

Chory przyjmowany do szpitala z HF w III lub IV klasie NYHA wymaga szybkiego postępowania zmierzającego do zredukowania duszności. Pacjent z towarzyszącym niepokojem powinien otrzymać morfinę, która wykazuje podwójny mechanizm działania: ośrodkowy - uspokajający oraz w mniejszym stopniu obwodowy - naczyniorozszerzający i zwalniający czynność serca. Lek należy podawać ostrożnie, szczególnie u osób w starszym wieku, ze względu na możliwe depresyjne działanie na centralny ośrodek oddechowy.

W celu zapewnienia maksymalnego dostarczania tlenu do tkanek, a przez to zapobiegania dysfunkcji narządów i niewydolności wielonarządowej, zaleca się utrzymywanie $\mathrm{SaO}_{2}$ w granicach normy (95-98\%) (zalecenie klasy IC). Pacjenci z saturacją poniżej 90\% lub prężnością tlenu w badaniu gazometrycznym poniżej $60 \mathrm{~mm} \mathrm{Hg}$, powinni otrzymywać tlen (zalecenie klasy IC). W przypadku znacznej hipoksemii można prowadzić wentylację nieinwazyjną za pomocą urządzeń do utrzymywania stałego dodatniego ciśnienia w drogach oddechowych: ciągłego dodatniego ciśnienia w drogach oddechowych (CPAP, continuous positive airway pressure) lub nosowej wentylacji przerywanym ciśnieniem dodatnim (NIPPV, nasal intermittent positive pressure). Nieinwazyjna wentylacja utrzymująca dodatnie ciśnienie w drogach oddechowych jest przeciwwskazana w przypadku ciśnienia skurczowego poniżej $85 \mathrm{~mm} \mathrm{Hg}$ oraz w przypadku prawokomorowej HF. Inwazyjną wentylację mechaniczną (z intubacją dotchawiczą) stosuje się przede wszystkim w celu odwrócenia zmęczenia mięśni oddechowych wywołanego AHF, a nie w celu zniesienia hipoksemii dającej się opanować tlenoterapią, CPAP lub NIPPV. Zmęczenie mięśni oddechowych można rozpoznać na podstawie zmniejszonej częstotliwości oddechów, związanej z hiperkapnią i obecności objawów splątania. Inwazyjną wentylację mechaniczną powinno się stosować tylko wtedy, gdy ostra niewydolność oddechowa nie odpowiada na leki rozszerzające naczynia, tlenoterapię, CPAP Iub NIPPV. Pacjent z saturacją ponad 90\% nie wymaga tlenoterapii (patrz także ryc. 2).

Lekiem pierwszego rzutu w leczeniu AHF jest lek odwadniający. Zazwyczaj pierwszą dawkę podaje lekarz pogotowia ratunkowego bądź lekarz szpitalnego oddziału ratunkowego. Wśród diuretyków największe znaczenie 


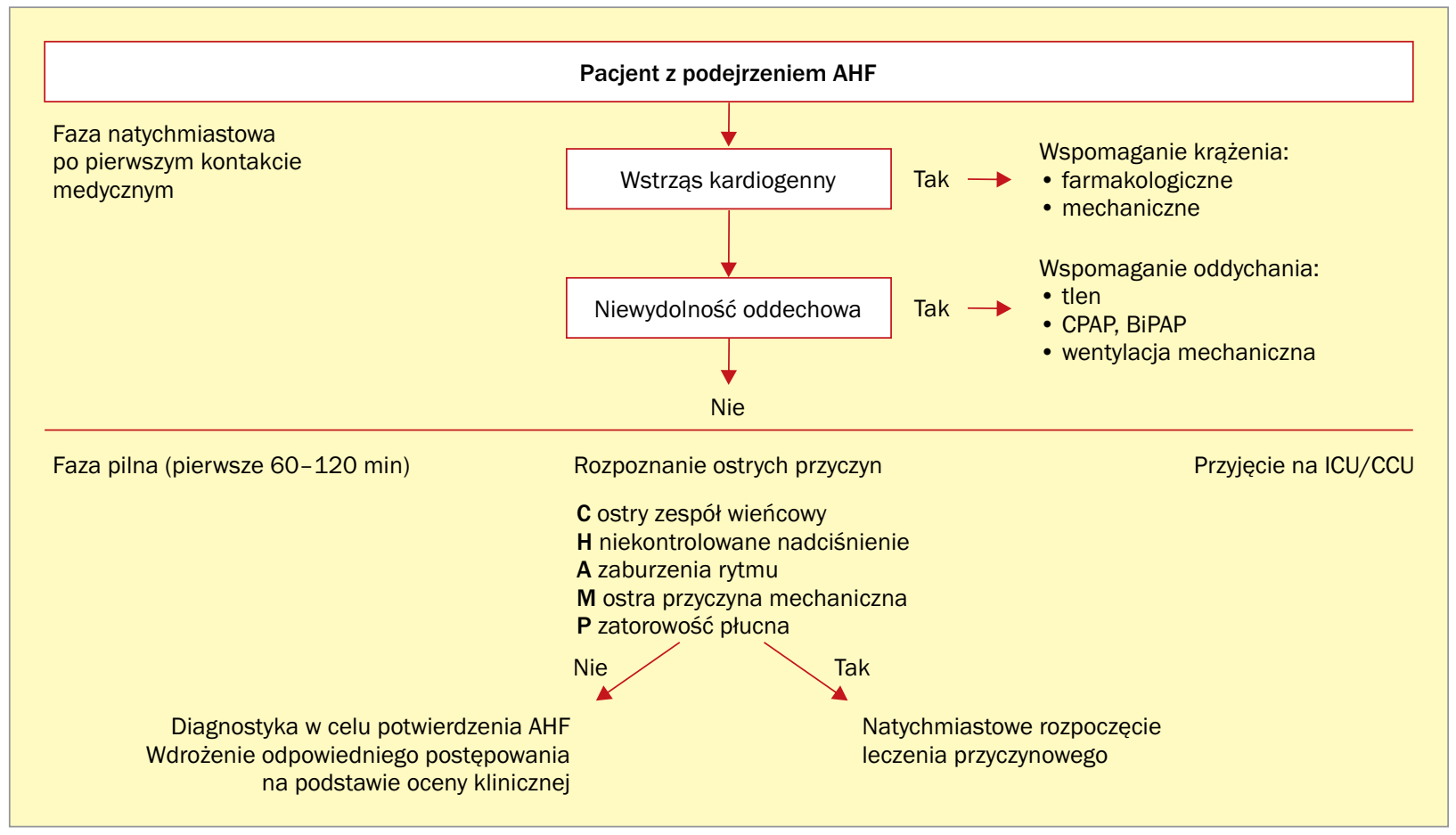

Rycina 1. Algorytm postępowania wstępnego u pacjenta z ostrą niewydolnością serca (AHF, acute heart failure) (zmodyfikowano na podstawie [1]); BiPAP (bilevel positive airway pressure) - dwufazowe dodatnie ciśnienie w drogach oddechowych; CCU (cardiology care unit) oddział intensywnej opieki kardiologicznej; CPAP (continous positive airway pressure) - ciągłe dodatnie ciśnienie w drogach oddechowych; ICU (intensive care unit) - oddział intensywnej terapii

Tabela 2. Objawy podmiotowe i przedmiotowe ostrej niewydolności serca (zmodyfikowano na podstawie [3])

\begin{tabular}{lll} 
Objawy związane z retencją płynów & Objawy związane z hipoperfuzją obwodową & Objawy o innym złożonym mechanizmie \\
\hline Zwiększenie masy ciała & Blada, zimna, spocona skóra & Hipotensja ortostatyczna \\
Trzeszczenia nad polami płuc & Zimne kończyny & IV ton serca \\
Cechy płynu w jamie opłucnej & Hipotonia & Szmery sercowe \\
Obrzęki obwodowe & Tętno nitkowate & \\
Zwiększony obwód brzucha & Niskie ciśnienie tętna & \\
Ból/dyskomfort w górnym prawym & Skąpomocz & \\
kwadrancie brzucha & \\
Hepatosplenomegalia & \\
Żółtaczka & \\
Zwiększone ciśnienie w żyłach szyjnych & \\
Refluks wątrobowo-szyjny & \\
III ton serca &
\end{tabular}

w leczeniu AHF mają diuretyki pętlowe, na czele z furosemidem w formie dożylnej. Droga podania wynika z upośledzonej absorpcji leku doustnego z przewodu pokarmowego w okresie dekompensacji HF [9]. Diuretyki pętlowe podawane dożylnie, oprócz działania moczopędnego, mają działanie wazodylatacyjne, przejawiające się między innymi spadkiem oporu w krążeniu płucnym, przez co obniżają obciążenie wstępne. Podczas stosowania dużych dawek (> $1 \mathrm{ml} / \mathrm{kg} \mathrm{mc}$.) w szybkim wlewie dożylnym może dojść do wystąpienia odruchowego skurczu naczyń [10]. Forma dożylna jest również preferowana ze względu na szybsze i pewniejsze działanie (furosemid w formie 


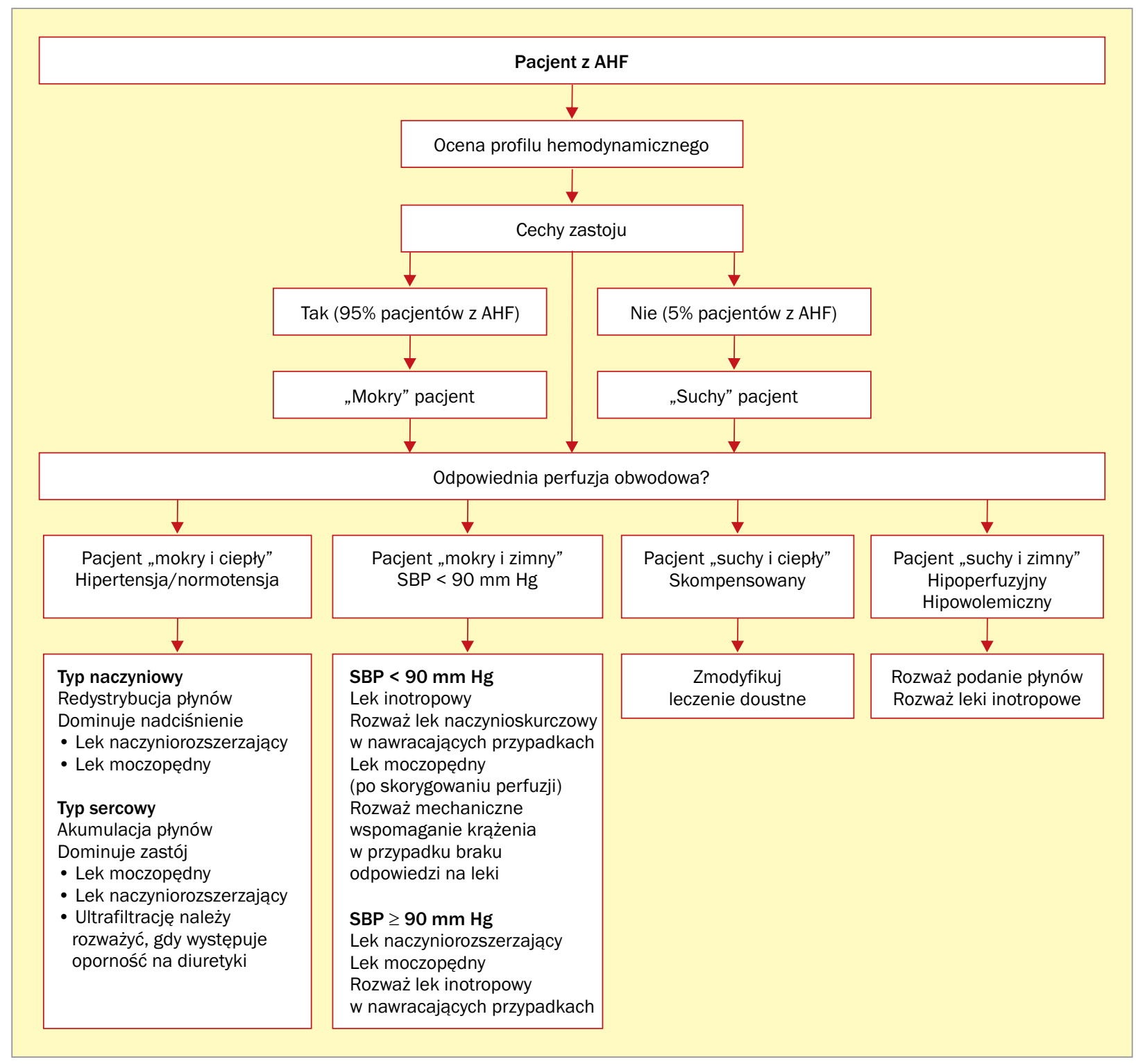

Rycina 2. Algorytm leczenia pacjenta z ostrą niewydolnością serca (AHF, acute heart failure) (zmodyfikowano na podstawie [1]); SBP (systolic blood pressure) - skurczowe ciśnienie tętnicze

doustnej działa po około $30 \mathrm{~min}, \mathrm{w}$ formie parenteralnej sześć razy szybciej - już po $5 \mathrm{~min}$ ). Dawka diuretyku ustalana jest indywidualnie i zależy między innymi od wydolności nerek oraz wcześniejszej terapii. Pacjenci z przewlekłą chorobą nerek mogą wymagać większych dawek. Charakterystyczne dla pacjentów dotychczas nieleczonych oraz pacjentów niestosujących się do zaleceń jest szybki efekt diuretyczny, w przeciwieństwie do chorych leczonych przewlekle, u których każda kolejna hospitalizacja może się wiązać z narastającą opornością na stosowane leczenie. W wytycznych zaleca się, by u chorych leczonych uprzednio diuretycznie stosować dawkę równoważną dawce dotychczas stosowanej lub 2,5-krotności tejże dawki [9].
W dostępnym piśmiennictwie oraz aktualnych wytycznych nie sprecyzowano sposobu podania diuretyku dożylnego w ostrej fazie - bolus v. wlew ciągły. Większa dawka pojedyncza (bolus) daje lepszy i szybszy efekt w redukcji objawów, jednakże częściej wpływa na pogorszenie parametrów nerkowych. Wlew dożylny natomiast zapewnia bardziej stabilne odwodnienie, z mniejszym prawdopodobieństwem zaostrzenia niewydolności nerek. Podczas wlewu ciągłego występują mniejsze wahania stężeń leku, przy jednocześnie mniejszym stężeniu maksymalnym, co wiąże się z redukcją działań niepożądanych [10]. Metaanalizy porównujące te dwie strategie leczenia sugerują przewage wlewu ciągłego. Podczas dożylnego odwadniania pacjent powinien być monitorowany zarówno klinicznie, jak i laboratoryjnie 
(codzienna ocena parametrów nerkowych i elektrolitów). Poza furosemidem coraz bardziej cenionym diuretykiem pętlowym jest torasemid. W porównaniu z furosemidem charakteryzuje się on dłuższym czasem działania, wyższą biodostępnością oraz aktywnością przeciwaldosteronową. Oba leki - furosemid w dawce $40 \mathrm{mg}$ i torasemid w dawce $10 \mathrm{mg}$ - porównano w badaniu TORIC (Torasemid in Congestive Heart Failure Study), w którym w grupie leczonej torasemidem stwierdzono mniejszą śmiertelność, szybszą poprawę kliniczną pacjentów i rzadsze występowanie hipokaliemii [11].

W przypadku nieodpowiedniej odpowiedzi na diuretyk zastosowany parenteralnie (diureza < $100 \mathrm{ml} / \mathrm{h}$ w ciągu 1-2 h) dotychczas zalecano podwojenie dawki diuretyku, maksymalnie do dawki równoważnej $500 \mathrm{mg}$ furosemidu [2]. W aktualnych wytycznych, w celu przełamania oporności na leki moczopędne, zaleca się już w fazie ostrej podwójną blokadę pętli nefronu za pomocą dwóch diuretyków o różnym punkcie uchwytu, tj. diuretyk pętlowy w połączeniu z lekami tiazydowymi lub diuretycznymi dawkami spironolaktonu $[1,10]$. Po uzyskaniu negatywnych wyników w badaniu ROSE (Renal Optimization Strategies Evaluation in Acute Heart Failure) eksperci w aktualnych standardach nie rekomendują stosowania dopaminy w tak zwanych dawkach diuretycznych [12]. Ta metoda leczenia jest jednak nadal dość powszechnie stosowana, w wielu ośrodkach zarówno polskich, jak i zagranicznych.

Problem z odwodnieniem często dotyczy chorych z zaburzoną czynnością nerek. W takim przypadku dawka diuretyku musi być znacznie większa niż u osoby z prawidłową ich funkcją. Podobnie pacjenci z niskim stężeniem albumin mogą opornie reagować na stosowane leczenie.

W wytycznych z 2016 roku wśród leków w terapii AHF zamieszczono antagonistę wazopresyny - tolwaptan $\left(\right.$ Samsca ${ }^{\circledR}$ ), preparat przeznaczony dla pacjentów przewodnionych, z oporną hiponatremią. W badaniu EVEREST (Efficancy of Vasopressin Antagonist In Heart Failure Outcome Study With Tolvaptan) stwierdzono, że doustna podaż tolwaptanu w grupie chorych ze stężeniem sodu poniżej $130 \mathrm{mEq} / \mathrm{l}$ poza efektywniejszą redukcją masy ciała i ograniczeniem zapotrzebowania na diuretyki podczas hospitalizacji zmniejsza również śmiertelność poszpitalną [13]. Lek dotychczas stosowano w leczeniu dorosłych pacjentów z niedoborem sodu, wtórnym do zespołu nieodpowiedniego wydzielania hormonu antydiuretycznego (SIADH, syndrome of inappropriate anti-diuretic hormone). Amerykańska Agencja ds. Żywności i Leków (FDA, Food and Drug Administration) zaleca maksymalnie 30-dniową terapię tolwaptanem oraz konieczność monitorowania parametrów wątrobowych ze względu na możliwe hepatotoksyczne działanie leku [14].

W przypadku masywnych obrzęków bardzo dobry efekt można uzyskać stosując dożylnie kanrenon (Aldactone ${ }^{\circledR}$ ). Postępowanie takie nie znajduje potwierdzenia w wytycz- nych, ale z praktycznego punktu widzenia przełamanie wtórnego hiperaldosteronizmu często pozwala opanować ostrą fazę dekompensacji. Skuteczność wynika z przerwania samonapędzającego się mechanizmu związanego z uruchomieniem przez mięsień sercowy aktywacji układu RAA.

W celu intensyfikacji leczenia krążeniowego w wytycznych zaleca się równoległe stosowanie leków rozszerzających naczynia bądź amin katecholowych. Decyzja odnośnie do leczenia addycyjnego zależy od wartości ciśnienia tętniczego. W przypadku ciśnienia skurczowego powyżej $90 \mathrm{~mm}$ Hg należy rozważyć dołączenie leku wazodylatacyjnego (np. nitroglicerynę w najmniejszej skutecznej dawce - zalecenie klasy IlaB) lub wlew nitroprusydyku sodu (zalecenie klasy IIbB). Postępowanie takie pozwala na zmniejszenie obciążania wstępnego i ułatwia perfuzję obwodową przez rozszerzenie naczyń - w zależności od dawek - początkowo żylnych, a następnie tętniczych. Mechanizmy, które zmniejszają objawy HF, mogą powodować pojawienie się działań niepożądanych, takich jak silny ból głowy czy hipotonia, które mogą być powodem zaprzestania leczenia. Warto również wspomnieć o oporności na lek, która może się rozwinąć po około 48 godzinach ciągłego stosowania. Nitroprusydek sodu jest najsilniejszym lekiem rozszerzającym naczynia, o bardzo krótkim okresie półtrwania (działanie kończy się wraz z zakończeniem podawania) [15]. W wyniku długotrwałego dożylnego podawania leku może dochodzić do gromadzenia się toksycznych metabolitów: tiocyjanków i cyjanków. Szczególnie dotyczy to chorych z niewydolnością nerek lub z uszkodzeniem wątroby. Aby uniknąć działań niepożądanych, nie należy stosować leku dłużej niż 48 godzin [16, 17].

Największe korzyści z zastosowania leczenia naczyniorozkurczowego obserwowano podczas włączenia terapii w okresie przedszpitalnym. Leki należy podawać ostrożnie u chorych z istotną stenozą mitralną lub aortalną, kardiomiopatią przerostową z zawężaniem drogi odpływu lewej komory oraz w zawale prawej komory [18].

W aktualnych wytycznych wymienia się również nesiritid - rekombinowaną formę ludzkiego BNP (lek niedostępny w Polsce). Poza działaniem naczyniorozszerzającym, wykazuje on również działanie moczopędne i natriuretyczne. Charakteryzuje się również korzystnym profilem hormonalnym przez zmniejszenie stężenia aldosteronu i endoteliny 1 [19]. Nie zwiększa zapotrzebowania serca na tlen, nie działa inotropowo dodatnio oraz nie wpływa na częstość rytmu serca i nie wywołuje działania proarytmicznego [16].

Pacjenci we wstrząsie kardiogennym z ciśnieniem skurczowym poniżej $90 \mathrm{~mm} \mathrm{Hg}$ powinni otrzymać lek inotropowy, najlepiej dobutaminę, z eskalowaniem dawki co 15 minut, w zależności od odpowiedzi i tolerancji [8]. W wytycznych zakłada się możliwość zastosowania nowych leków inotropowych, takich jak lewosimendan, 
jednak w polskich realiach terapia $-z$ uwagi na koszt (ok. 3 tys. PLN za ampułkę) - jest mało dostępna. Lewosimendan poprzez wiązanie się z podjednostką sercowej troponiny C uwrażliwia kardiomiocyty na jony wapnia, bez wpływu na ich wewnątrzkomórkowe stężenie, przez co zwiększa kurczliwość mięśnia sercowego. Odbywa się to bez wpływu na wewnątrzkomórkowe stężenie cyklicznego adenozynomonofosforanu (cAMP, cyclic adenosine monophosphate), a przez to bez wzrostu zapotrzebowania mięśnia sercowego na tlen, co odróżnia lewosimendan od innych, „klasycznych” leków inotropowo dodatnich. Ponadto lewosimendan powoduje aktywację błonowych kanałów potasowych w naczyniach obwodowych, co skutkuje ich relaksacją. Konsekwencją tego jest redukcja obciążenia wstępnego i następczego, spadek oporu płucnego i obwodowego, a także poprawa perfuzji wieńcowej [20]. Stosowanie tego leku jest szczególnie korzystne w grupie pacjentów stosujących przewlekle ß-adrenolityki w celu odwrócenia efektu zablokowania receptorów $B$, gdy podejrzewa się jatrogenną przyczynę hipoperfuzji. Ze względu na wspomniane działanie naczyniorozszerzające lewosimendanu u pacjentów z ciśnieniem tętniczym poniżej $85 \mathrm{~mm} \mathrm{Hg}$ wskazane jest stosowanie go łącznie z innym lekiem inotropowym lub obkurczającym naczynia [1]. W przypadku utrzymywania się hipotonii, pomimo stosowania leku inotropowego, należy rozważyć dołączenie noradrenaliny, leku obkurczającego naczynia obwodowe, powodującego redystrybucję krwi do życiowo ważnych narządów - niestety, kosztem wzrostu obciążenia następczego [1]. Dawkowanie poszczególnych leków zamieszczono $w$ tabeli 3.

W celu pilnej kontroli częstotliwości rytmu komór u pacjenta z szybkim migotaniem przedsionków należy rozważyć podanie digoksyny, z redukcją dawki w przypadku niewydolności nerek. Dodatkowym efektem działania glikozydów naparstnicy jest nieznaczna poprawa rzutu serca oraz zmniejszenie ciśnienia napełniania lewej komory. Efekt ten jest wynikiem ich działania inotropowo dodatniego i chronotropowo ujemnego [16]. Można rozważyć również zastosowanie amiodaronu.

Leczenie AHF polega na ograniczeniu objawów oraz aktywnym poszukiwaniu przyczyny dekompensacji. Aby w codziennej praktyce ułatwić szybką identyfikację najczęstszych odwracalnych przyczyn AHF (patrz ryc. 1), autorzy wytycznych zaproponowali skrót CHAMP od angielskich słów: C - ostry zespół wieńcowy (acute Coronary syndrome), $\mathbf{H}$ - niekontrolowane nadciśnienie tętnicze (Hypertension emergency), A - zaburzenia rytmu serca (Arrhytmia), M ostra przyczyna mechaniczna (acute Mechanical cause), P - zatorowość płucna (Pulmonary embolism).

W przypadku ostrego zespołu wieńcowego wskazana jest pilna koronarografia z angioplastyką. U chorych z dysfunkcją zastawkową (infekcyjne zapalenie wsierdzia/zdekompensowana wada zastawkowa bądź dysfunkcja sztucznej zastawki)
Tabela 3. Dawkowanie leków rozszerzających naczynia i leków inotropowych (na podstawie [1])

\begin{tabular}{|c|c|}
\hline $\begin{array}{l}\text { Leki rozszerzające } \\
\text { naczynia }\end{array}$ & Dawkowanie \\
\hline Nitrogliceryna & $10-20 \mu \mathrm{g} / \mathrm{min}-200 \mu \mathrm{g} / \mathrm{min}$ \\
\hline Diazotan izosorbidu & $1-10 \mathrm{mg} / \mathrm{h}$ \\
\hline Nitroprusydek & 0,3-5 $\mu \mathrm{g} / \mathrm{kg} \mathrm{mc} . / \mathrm{min}$ \\
\hline Nesiritid & Bolus $2 \mu \mathrm{g} / \mathrm{kg} \mathrm{mc} .+$ wlew 0,01 $\mu \mathrm{g} / \mathrm{kg} \mathrm{mc}$. \\
\hline Leki inotropowe & Dawkowanie \\
\hline Dobutamina & $2-20$ g/kg mc./min (beta +) \\
\hline Dopamina & $\begin{array}{l}\text { 3-5 } \mu \mathrm{g} / \mathrm{kg} \mathrm{mc} . / \mathrm{min} \text { inotropowo (beta }+ \text { ) } \\
>5 \mu \mathrm{g} / \mathrm{kg} \mathrm{mc} . / \mathrm{min}(\text { beta }+ \text { ) naczynio- } \\
\text { skurczowo }(\text { alfa }+ \text { ) }\end{array}$ \\
\hline Milrinon & $\begin{array}{l}\text { Bolus } 25-75 \mu \mathrm{g} / \mathrm{kg} \mathrm{mc} . \text { przez } 10-20 \mathrm{~min} \\
0,375-0,75 \mu \mathrm{g} / \mathrm{kg} \mathrm{mc} . / \mathrm{min}\end{array}$ \\
\hline Enoksymon & $\begin{array}{l}\text { Bolus } 0,5-1 \mathrm{mg} / \mathrm{kg} \mathrm{mc} \text {. przez 5-10 min } \\
5-20 \mu \mathrm{gg} / \mathrm{kg} \mathrm{mc} . / \mathrm{min}\end{array}$ \\
\hline Lewosimendan & 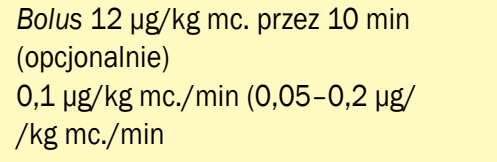 \\
\hline Noradrenalina & 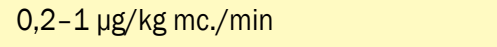 \\
\hline Adrenalina & $\begin{array}{l}\text { Bolus } 1 \mathrm{mg} \text { i.v. podawać co } 3-5 \mathrm{~min} \\
\text { podczas resuscytacji; 0,05-0,5 } \mathrm{mg} / \\
\text { /kg mc./min }\end{array}$ \\
\hline
\end{tabular}

zaleca się wyrównanie stanu klinicznego, a następnie korekcję kardiochirurgiczną. Chorzy z groźnymi arytmiami wymagają pilnej kardiowersji. W przypadku tachyarytmii należy zwolnić częstość rytmu, a pacjentów z wolnymi rytmami w przebiegu bloków przewodzenia zabezpieczyć stymulacją zewnętrzną. W przypadku infekcji leczenie stanu zapalnego obejmuje antybiotykoterapię empiryczną oraz w razie konieczności leczenie bronchodylatacyjne.

W przypadku braku efektu powyższych działań należy wdrożyć metody pozafarmakologiczne, do których należą mechaniczne wspomaganie krążenia (wskazanie llaC u chorych z odwracalną przyczyną zaostrzenia, np. u chorych z zapaleniem mięśnia sercowego lub u chorych z mechanicznymi powikłaniami zawału serca wskazanie klasy IlbC) czy leczenie nerkozastępcze.

Kontrapulsacja wewnątrzaortalna (IABP, intra-aortic balloon pump) była metodą od dawna stosowaną w leczeniu wstrząsu kardiogennego. Wyniki randomizowanego badania IABP-SHOCK II (The Intraaortic Balloon Pump in Cardiogenic Shock II) zakwestionowały skuteczność powyższego leczenia [21]. Poza IABP do mechanicznych metod wspomagania krążenia należą urządzenie wspomagające pracę lewej komory (LVAD, left ventricular assist device) czy urządzenie do pozaustrojowego utlenowania krwi (ECMO, 
extracorporeal membrane oxygenation). Urządzenia te pomagają zachować prawidłowy rzut serca oraz perfuzję obwodową. ECMO żylno-tętnicze zapewnia pacjentowi pełne wsparcie hemodynamiczne. Systememami wspomagania komór działającymi na podobnej zasadzie jak ECMO są system CentriMag oraz Impella. Urządzenia praktycznie możliwe do zastosowania jedynie w nielicznych ośrodkach z zapleczem kardiochirurgicznym. Systemy mechanicznego wspomagania krążenia (MCS, mechanical circulatory support) często stosowane są jako „pomost do decyzji” (BTD, bridge to decision) u pacjentów niereagujących na leczenie farmakologiczne, z ostrą i gwałtownie pogarszającą się HF w celu stabilizacji hemodynamicznej i umożliwienia pełnej oceny klinicznej pod kątem ewentualnego przeszczepienia lub zastosowania elektroterapii [1]. U części chorych urządzenia te pozostają terapią przewlekłą lub docelową. W metaanalizach porównujących terapię chorych za pomocą IABP w porównaniu z MCS, mechaniczne metody wspomagania krążenia charakteryzowały się lepszym profilem hemodynamicznym, przy zwiększonym ryzyku powikłań krwotocznych i brakiem wpływu na 30-dniową śmiertelność. Leczenie tak obciążonych pacjentów wymaga indywidualnego podejścia, gdyż dostępne badania były przeprowadzone na nielicznej grupie chorych.

W przypadku znacznego przeciążenia płynami i oporności na diuretyki należy rozważyć ultrafiltrację. Na podstawie metaanaliz 12 randomizowanych badań udokumentowano, że ultrafiltracja, skuteczniej niż leczenie diuretykami eliminuje przewodnienie, pozostając jednak bez wpływu na częstość hospitalizacji i śmiertelność [22].

Poza przypadkami niestabilności hemodynamicznej, u pacjentów z zaostrzeniem przewlekłej HF, w trakcie hospitalizacji należy kontynuować leczenie o udowodnionej skuteczności. Wyniki przeprowadzonych metaanaliz wykazały, że przerwanie przewlekłej terapii $\beta$-adrenolitykami wiązało się z istotnym zwiększeniem śmiertelności wewnątrzszpitalnej i poszpitalnej oraz zwiększało ryzyko rehospitalizacji [1].

Po uzyskaniu stabilizacji stanu klinicznego dalsze postępowanie jest analogiczne do postępowania w przewlekłej HF (ryc. 3).

\section{Leki w fazie badań}

Biorąc pod uwage wzrastającą liczbę chorych z AHF oraz to, że postępowanie z chorymi hospitalizowanymi z powodu AHF na przestrzeni ostatnich dekad nie uległo istotnej zmianie, oczywiste wydaje się ciągłe poszukiwanie nowych metod terapii, które poza działaniem objawowym w ostrej fazie, zabezpieczałoby chorego przed kolejną hospitalizacją i przedłużałyby mu życie w dobrym stanie.

W kwietniu 2017 roku podczas Kongresu Niewydolności Serca w Paryżu ogłoszono wyniki badania o akronimie TRUE-AHF (Trial of Ularitide's Efficacy and safety in patients with Acute Heart Failure), w którym oceniano skuteczność działania ularytydu - syntetycznej formy urodylatyny, natriuretycznego peptydu syntetyzowanego w nerkach [23]. Nie potwierdzono hipotezy, że dożylny 48-godzinny wlew ularytydu w porównaniu z wlewem placebo, dołączony do standardowej terapii AHF, zmniejszy śmiertelność oraz liczbę rehospitalizacji w 6-miesięcznej obserwacji [24, 25].

Podobnie, nie udało się potwierdzić skuteczności serelaksyny (REASANS ${ }^{\mathrm{TM}}$ ), z którą wiązano największe nadzieje, zwłaszcza po ogłoszeniu wyników badania RELAX-AHF (RELAXin in Acute Heart Failure). Ta rekombinowana forma ludzkiej relaksyny 2, polipeptydu fizjologicznie występującego u kobiet w ciąży, we wspomnianym badaniu wykazała zmniejszenie objawów HF w obserwacji krótkoterminowej oraz zmniejszenie o 37\% śmiertelności całkowitej w ciągu 180-dniowej obserwacji. Europejska Agencja Leków (EMA, European Medicines Agency) uznała jednak, że wyniki badania RELAX-AHF są niewystarczająco przekonujące z powodów metodologicznych i odrzuciła wniosek rejestracyjny.

Zainicjowane w 2013 roku na większej populacji chorych badanie RELAX-AHF-2, którego wyniki również ogłoszono w tym roku, nie potwierdziło skuteczności serelaksyny u pacjentów z AHF. Między grupami nie było statystycznie istotnych różnic w punktach końcowych. Mimo przekonania autorów badania, że jego niepowodzenie wynika z nieprawidłowej selekcji chorych, a nie z braku skuteczności cząsteczki, na pewno armamentarium leków stosowanych u chorych z AHF w najbliższym czasie nie ulegnie zmianie.

\section{Podsumowanie}

Ostra niewydolność serca stanowi poważny problem socjoekonomiczny współczesnego świata. W opiece nad chorym wysiłki zmierzają jednocześnie do zmniejszenia objawów związanych z HF, odpowiedniego leczenia chorób prowadzących do jej rozwoju, zwłaszcza choroby wieńcowej, oraz do poprawy jakości życia chorych. W ostatnich latach znacznie obniżyła się śmiertelność wewnątrzszpitalna, jednak zarówno częstość rehospitalizacji, jak i śmiertelność poszpitalna w okresie 60-90 dni po wypisaniu pozostaje wysoka. Szacuje się je, odpowiednio, na 30 i 15\% [3]. Postuluje się holistyczne podejście do chorych wypisywanych ze szpitala po incydencie AHF, z uwzględnieniem edukacji pacjentów i ich rodzin odnośnie do terapii, regularnej kontroli masy ciała, ograniczenia soli i ilości przyjmowanych płynów, modyfikacji stylu życia oraz konieczności systematycznego wysiłku aerobowego w celu poprawy wydolności fizycznej i zmniejszenia objawów klinicznych. Należy uwrażliwiać chorych na możliwe czynniki wywołujące dekompensacje HF. W polskich warunkach jednym z problemów w dalszej opiece nad chorym w ramach 


\section{Pacjent z objawowa HFrEF}

Leki moczopędne w celu zmniejszania objawów zastoju

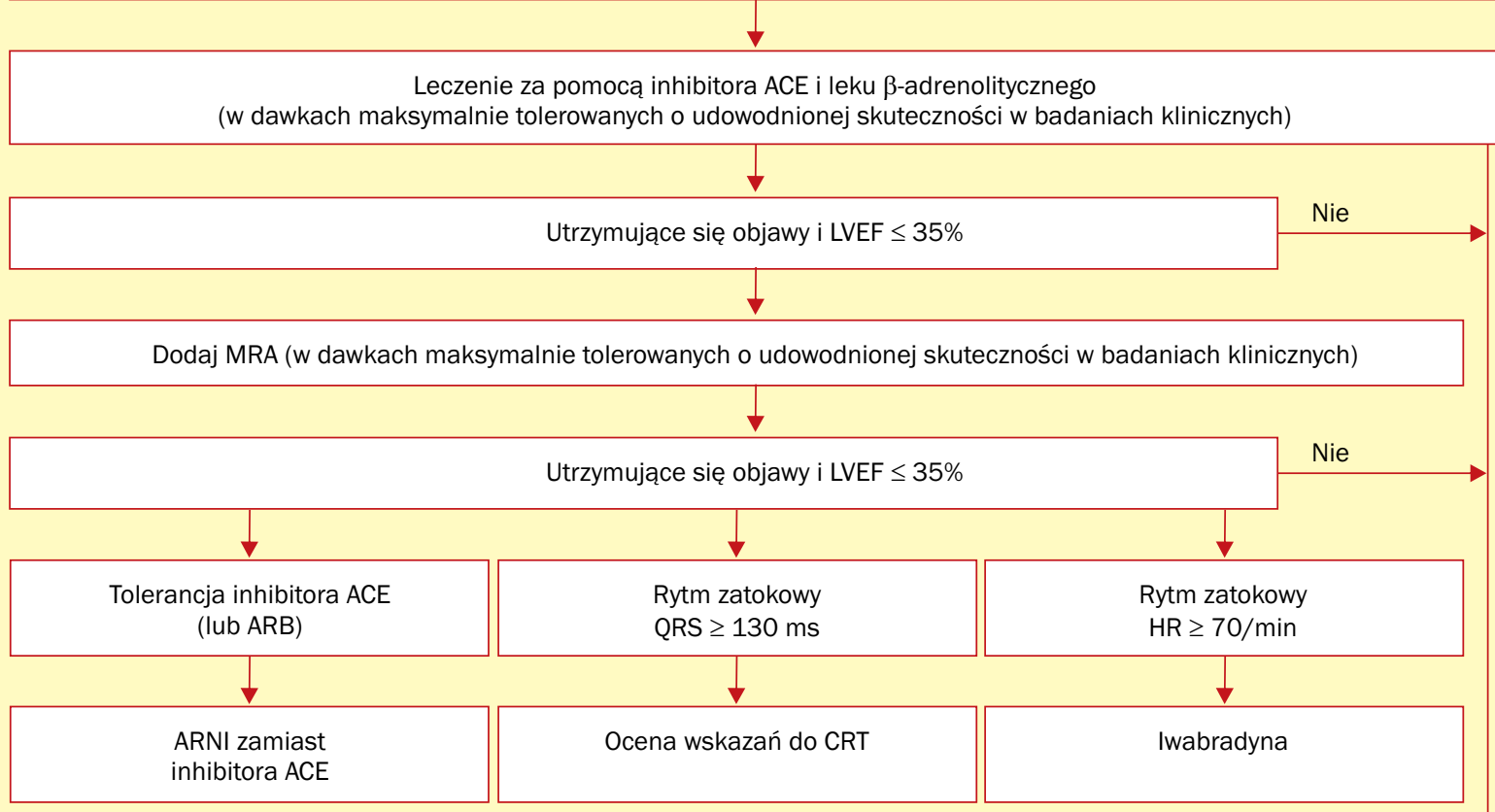

Powyższe metody leczenia można łączyć ze sobą

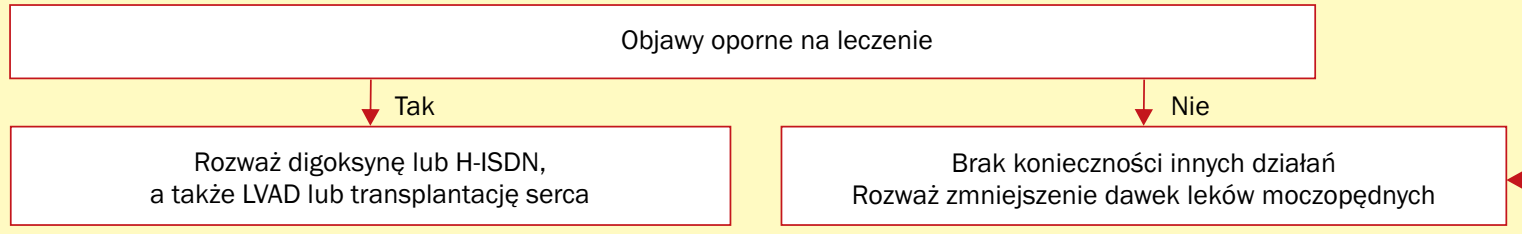

Rycina 3. Opcje terapeutyczne u pacjentów z przewlekłą niewydolnością serca z obniżoną frakcją wyrzutową lewej komory (HFrEF, heart failure with reduced left ventricular ejection fraction) (na podstawie [1]); ACE (angiotensin-converting enzyme) - konwertaza angiotensyny; LVEF (left ventricular ejection fraction) - frakcja wyrzutowa lewej komory; MRA (mineralocorticoid receptor antagonist) - antagonista receptora mineralokortykoidowego; ARB (angiotensin receptor blocker) - antagonista receptora dla angiotensyny II; HR (heart rate) - rytm serca; ARNI (angiotensin receptor neprilisin inhibitor) - antagonista receptora angiotensyny i inhibitor neprilizyny; CRT (cardiac resynchronization therapy) - terapia resynchronizująca serca; H-ISDN (hydralazine-isosorbide dinitrate) - połączenie hydralazyny i diazotanu izosorbidu; LVAD (left ventricular assist device) - urządzenie wspomagające pracę lewej komory

podstawowej opieki zdrowotnej (POZ) jest brak optymalizacji leczenia zainicjowanego w trakcie hospitalizacji. W ten sposób pozbawia się chorych korzystnych efektów leczenia potwierdzonego w badaniach klinicznych. Innym istotnym mankamentem jest brak wystarczającej opieki ambulatoryjnej ze strony poradni kardiologicznych nad chorymi z HF, zwłaszcza tymi z grupy najwyższego ryzyka, wymagającymi niejednokrotnie wnikliwej oceny kardiologa, popartej obiektywnymi wynikami badań dodatkowych, którzy - pozbawieni takiej opieki - często trafiają do szpitala z powodu zaostrzeń HF. Narodowy Fundusz Zdrowia w zasadach finansowania, nie dywersyfikując kosztów opieki nad pacjentami z różnych grup ryzyka, promuje pacjenta wymagającego jak najmniejszego nakładu finansowego na diagnostykę i leczenie -między innymi kosztem pacjentów z ciężką HF.

Świadomość olbrzymich kosztów leczenia szpitalnego pacjentów z HF oraz jeden z najwyższych na świecie wskaźników liczby hospitalizacji z powodu HF w przeliczeniu na liczbę mieszkańców powinny być zachętą dla osób decyzyjnych w Polsce do racjonalnego podziału środków na opiekę szpitalną i ambulatoryjną nad chorymi z HF. Bez tego implementacja nawet najlepszych zaleceń nie będzie możliwa.

\section{Konflikt interesów}

Autorzy deklarują brak konfliktu interesów. 


\section{Abstract}

Acute heart failure (AHF) is a major and growing public health problem worldwide with ten million patients in Europe and eight hundred thousand patients in Poland. AHF is defined as the rapid onset of, or change in, signs and symptoms of heart failure (HF) requiring urgent therapy and hospitalization. It arises from a rapid appearance for the first time or as a result of deterioration in patients with a previous diagnosis of HF. Fast diagnosis and treatment, initially focused on symptom relief and causal treatment is crucial. This article is the summary of the new European Society of Cardiology guidelines for the diagnosis and treatment of acute and chronic heart failure and short overview of ongoing multicenter studies are still lacking on the pharmacotherapy of AHF.

Key words: acute heart failure, diuretics, inotropic agents, ularitide, serelaxin

Folia Cardiologica 2017; 12, 3: 306-316

\section{Piśmiennictwo}

1. Ponikowski P, Voors A, Anker S, et al. Wytyczne ESC dotyczące diagnostyki i leczenia ostrej i przewlekłej niewydolności serca w 2016 roku. Kardiol Pol. 2016; 74(10): 1037-1147, doi: 10.5603/kp.2016.0141.

2. Gierczyński J, Gryglewicz J, Karczewicz E, Zalewska H. Niewydolność serca - analiza kosztów ekonomicznych i społecznych. Uczelnia Łazarskiego, Warszawa 2013.

3. Sosnowska-Pasiarska B, Bartkowiak R, Wożakowska-Kapłon B, et al. Population of Polish patients participating in the Heart Failure Pilot Survey (ESC-HF Pilot). Kardiol Pol. 2013; 71(3): 234-240, doi: 10.5603/KP.2013.0034, indexed in Pubmed: 23575777.

4. Fonarow GC, Heywood JT, Heidenreich PA, et al. ADHERE Scientific Advisory Committee and Investigators. Temporal trends in clinical characteristics, treatments, and outcomes for heart failure hospitalizations, 2002 to 2004: findings from Acute Decompensated Heart Failure National Registry (ADHERE). Am Heart J. 2007; 153(6): 1021-1028, doi: 10.1016/j.ahj.2007.03.012, indexed in Pubmed: 17540205.

5. The ADHERE (Acute Decompensated Heart Failure National Registry) Registry. Background and Q1 2006 Final Cumulative Benchmark Report. http://www.sciosinc.com/sciosinc/adhere.html.

6. Gheorghiade M, Abraham WT, Albert NM, et al. OPTIMIZE-HF Investigators and Coordinators. Systolic blood pressure at admission, clinical characteristics, and outcomes in patients hospitalized with acute heart failure. JAMA. 2006; 296(18): 2217-2226, doi: 10.1001/ /jama.296.18.2217, indexed in Pubmed: 17090768.

7. Nieminen MS, Brutsaert D, Dickstein K, et al. EuroHeart Survey Investigators, Heart Failure Association, European Society of Cardiology. EuroHeart Failure Survey II (EHFS II): a survey on hospitalized acute heart failure patients: description of population. Eur Heart J. 2006; 27(22): 2725-2736, doi: 10.1093/eurheartj/ehl193, indexed in Pubmed: 17000631.

8. Dorrance A. Faculty of 1000 evaluation for ESC Guidelines for the diagnosis and treatment of acute and chronic heart failure 2012: the Task Force for the Diagnosis and Treatment of Acute and Chronic Heart Failure 2012 of the European Society of Cardiology. Developed in collaboration with the Heart Failure Association (HFA) of the ESC. F1000 - Post-publication peer review of the biomedical literature. do i: 10.3410/f.718489795.793497182.

9. Bart BA, Goldsmith SR, Lee KL, et al. NHLBI Heart Failure Clinical Research Network. Diuretic strategies in patients with acute decompensated heart failure. N Engl J Med. 2011; 364(9): 797-805, doi: 10.1056/NEJMoa1005419, indexed in Pubmed: 21366472.
10. Channer KS, McLean KA, Lawson-Matthew P, et al. Combination diuretic treatment in severe heart failure: a randomised controlled trial. Br Heart J. 1994; 71(2): 146-150, indexed in Pubmed: 8130022.

11. Cosín J, Díez J. TORIC Investigators. Torasemide in chronic heart failure: results of the TORIC study. Eur J Heart Fail. 2002; 4(4): 507-513, indexed in Pubmed: 12167392.

12. Chen HH, Anstrom KJ, Givertz MM, et al. NHLBI Heart Failure Clinical Research Network. Low-dose dopamine or low-dose nesiritide in acute heart failure with renal dysfunction: the ROSE acute heart failure randomized trial. JAMA. 2013; 310(23): 2533-2543, doi: 10.1001/ /jama.2013.282190, indexed in Pubmed: 24247300.

13. Felker GM, Mentz RJ, Adams KF, et al. Tolvaptan in patients hospitalized with acute heart failure: rationale and design of the TACTICS and the SECRET of CHF trials. Circ Heart Fail. 2015; 8(5): $997-$ -1005, doi: 10.1161/CIRCHEARTFAILURE.115.002259, indexed in Pubmed: 26374918.

14. Stuart C. FDA puts 30-day limit on tolvaptan for heart failure patients, Cardiovascular Business. www.cardiovascularbusiness.com/ /topics/heart-failure/fda-puts-30-day-limit-tolvapten-heart-failure-patients (02.12.2016).

15. Lewis N. Nitroprusside toxicity. Emerg Med. 2000; 32: 71-75.

16. Ciurus T, Berner J, Lelonek M. Farmakoterapia ostrej niewydolności serca. Terapia. 2015; 9: 69-75.

17. Leczenie ogólne w ostrej niewydolności serca. Termedia. www.termedia.pl/Leczenieogolnewostrejniewydolnosciserca 45,8383,1,0. $\mathrm{html}$ (01.09.2016).

18. Sekcja Niewydolności serca PTK, Niewydolność serca w Polsce - raport 2016. http://www.niewydolnosc-serca.pl/barometr.pdf (22.11.2016).

19. Anderson TJ, Meredith IT, Ganz P, et al. Nitric oxide and nitrovasodilators: similarities, differences and potential interactions. J Am Coll Cardiol. 1994; 24(2): 555-566, indexed in Pubmed: 8034895.

20. Biegus J, Zymliński R, Kulej K, et al. Zastosowanie lewosimendanu u chorych z ostrą niewydolnością serca z objawami małego rzutu minutowego serca: opis serii przypadków. Kardiol Pol. 2013; 71(3): 275-278, doi: 10.5603/kp.2013.0041.

21. Thiele H, Schuler G, Neumann FJ, et al. IABP-SHOCK II Trial Investigators. Intraaortic balloon counterpulsation in acute myocardial infarction complicated by cardiogenic shock: Design and rationale of the Intraaortic Balloon Pump in Cardiogenic Shock II (IABP-SHOCK II) trial. Am Heart J. 2015; 169(4): e7-e8, doi: 10.1016/j.ahj.2015.01.009, indexed in Pubmed: 25819870. 
22. Kwong JSW, Yu CM. Ultrafiltration for acute decompensated heart failure: a systematic review and meta-analysis of randomized controlled trials. Int J Cardiol. 2014; 172(2): 395-402, doi: 10.1016/j. ijcard.2014.01.069, indexed in Pubmed: 24512880.

23. http://www.cardiorentis.com/de/rd/true-ahf.php (01.09.2016).

24. Anker SD, Ponikowski P, Mitrovic V, et al. Ularitide for the treatment of acute decompensated heart failure: from preclinical to clinical stud- ies. Eur Heart J. 2015; 36(12): 715-723, doi: 10.1093/eurheartj/ /ehu484.

25. Serelaxin fails to meet primary endpoints in phase 3 RELAX-AHF-2 trial. https://www.escardio.org/The-ESC/Press-Office/Press-releases/serelaxin-fails-to-meet-primary-endpoints-in-phase-3-relax-ahf-2-trial (18.05.2017). 